\title{
Physical Risk Assessment for Urban Water Supply in a Developing Country: A Case of Mega City Dhaka
}

\author{
Shahriar Shams ${ }^{1}$, Amimul Ahsan ${ }^{2, a, b, *}$, Abdullah Al-Mamun ${ }^{3}$, \\ and Thirugnanasambantham Arunkumar ${ }^{4}$ \\ 1 Civil Engineering, Institut Teknologi Brunei (ITB), Brunei Darussalam \\ 2 Dept. of Civil Engg., \& Institute of Advanced Technology, University Putra Malaysia, 43400 Serdang, \\ Malaysia \\ 3 Bioenvironmental Engineering Research Centre (BERC), Kulliyyah of Engineering, International Islamic \\ University of Malaysia (IIUM), Jalan Gombak, 53100 Kuala Lumpur, Malaysia \\ 4 Institute for Energy Studies, Anna University, Chennai, 600025, Tamil Nadu, India \\ *E-mail: aashikcivil@yahoo.com, bamimul@upm.edu.my (Corresponding author)
}

\begin{abstract}
Water supply access in many developing countries is yet to fulfill Millennium Development Goals. Many local governments are incapable of managing their water resources either due to funding constrains or lack of adequate work force. This often results into poor services with low quality, insufficient and inconsistent delivery of water, leakage and wastage creating water shortages. The water stress resulting from urbanization is more acute in terms of Dhaka city due to its capital city-centric development strategies attracting rural-urban migration, which have resulted into an unplanned horizontal and vertical expansion of the city without having facilities for relevant infrastructures. Therefore, it is important to carry out a risk assessment on existing water supply distribution systems to address the challenges of frequent leaks contributing to cross contamination and system loss arising from unplanned development and aging of pipes. The objective of this study is to identify the physical risk for various zones under Dhaka City based on existing distribution systems and its susceptibility to leakage. The assessment requires analyses of distribution system, its length, number of leaks in the pipes detected every month, population density, number of consumers, characteristics of areas whether industrial or residential areas, low lying and vulnerable to flooding. The study finds that Zone IV possesses a very high risk due to an average leak of 93 per month with 1,571,960 people are exposed to vulnerability while Zone II, III, V, VI having average monthly leaks of 39, 36, 26, and 34 respectively are high risk zones.
\end{abstract}

Keywords: DWASA, risk assessment, water supply, flood.

ENGINEERING JOURNAL Volume 20 Issue 3

Received 28 July 2015

Accepted 30 November 2015

Published 19 August 2016

Online at http://www.engj.org/

DOI:10.4186/ej.2016.20.3.23 


\section{Introduction}

It is estimated that as many as 768 million people lack access to potable water in the world [1]. Easy access to potable, safe and affordable water is one of the most important criteria for human survival. It ensures social, and economic growth, promotes health and overall welling being of human being. It is estimated the number of vulnerable cities facing serious water crisis will go up from 25 to 32 , representing a $28 \%$ increase by 2040 [2]. It has been very cost effective to improve health and living condition through comprehensive management of drinking water supply and sanitation [3]. It is projected that return on investment on water and sanitation services is $\$ 5-\$ 28$ for each $\$ 1$ invested in developing countries [4]. It is thus important for the water experts and specialists to convey this important message to the politicians and decision makers. Therefore, the law-makers can be motivated to invest more in water related projects compared to structural projects [5]. The safe water supply can ensure sustainability for development in rural and urban environment [6]. It will substantially reduce the loss of lives resulting from water related diseases and reduce burden on limited health services, particularly in developing countries. According to the UN-Water report [7], diarrhea alone is responsible for the death of five thousand children each day. The target for Millennium Development Goal (MDG) is yet to be achieved in urban areas of many developing countries due to rapid growth in unplanned fashion [4]. In fact, there was an increase to 149 million people from 111 million people in urban areas without access to suitable drinking water [8]. Nevertheless, the percentage of people having access to piped water supply increased from 51\% to 54\% for Southern Asia as shown in Fig. 1.

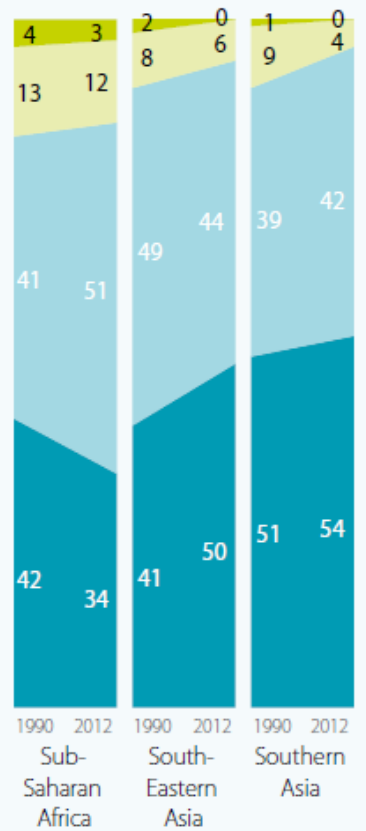

Piped on premises

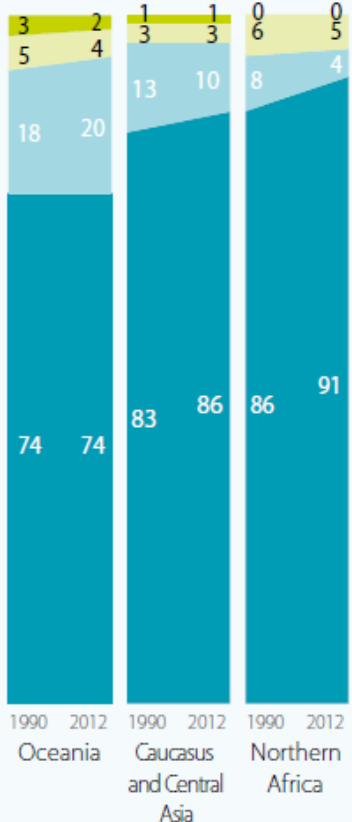

Other improved
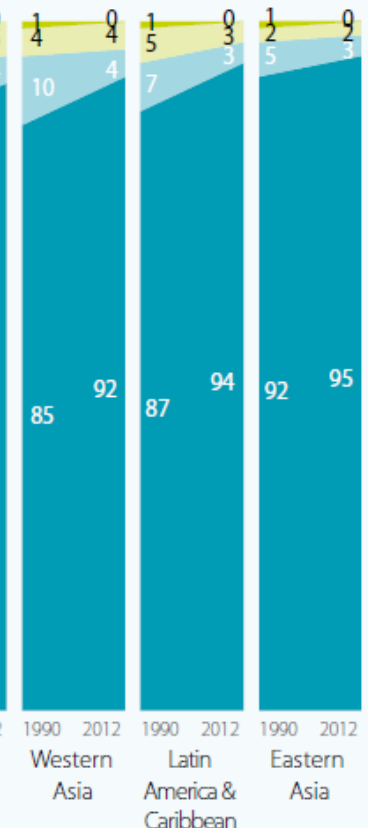
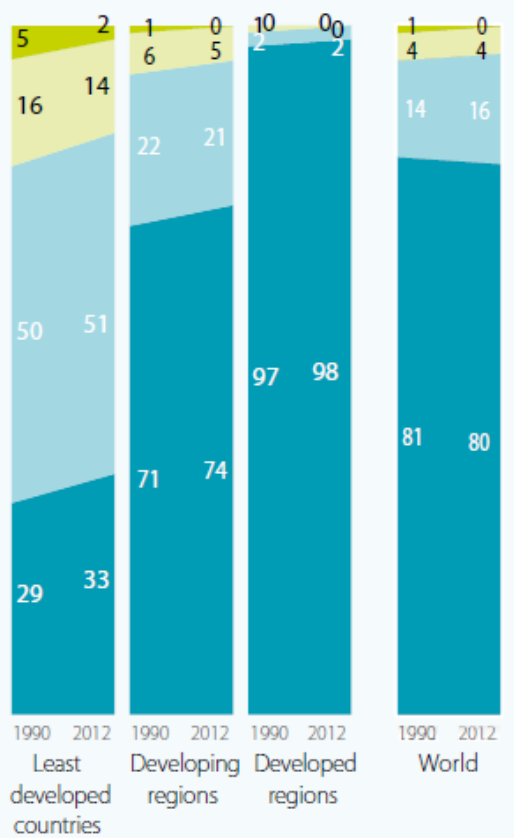

Fig. 1. Trends of urban water supply coverage 1990-2012 [8].

Many local governments are incapable of managing their water resources either due to fund constrains or lack of adequate work force. This often results into poor services with low quality, insufficient and inconsistent delivery of water, leakage and wastage creating water shortages. Water supply access in most developing countries is complex [9, 10]. Increasing standards of living and population growth are the driving forces for increased domestic water use and it is projected to increase by $130 \%$ by 2050 in developing countries [1]. Population growth, economic development and climate change are the driving forces [11] for temporal and spatial variability of availability of water [12] aggravating water crisis and leading to water scarcity. The rapidly increasing demand for water is a major challenge to sustainability and short term solutions often leading to serious long term problems [13]. The problems are very acute in 
densely populated slum areas of the developing countries. Urbanization is occurring throughout the developing world at alarming rate of which $40 \%$ is the expansion of slums [4] and its population in Africa and Asia will double by 2030 [14].

In 2014, 54\% of the global population which is 3.9 billion lived in cities [15]. The problem of urbanization is more acute in Dhaka city due to its capital city-centric development strategies attracting rural-urban migration which have resulted into an unplanned horizontal and vertical expansion of the city without having facilities for relevant infrastructure [16]. Outbreaks of cholera and other water related diseases still possess a challenge in poor peri-urban and slum areas due to migration of rural people to urban areas [8]. In developing countries, water supply is provided to secure sufficient amounts of treated water of good quality [17]. Many households do not have piped water supply and have to rely on community based water sources. These include a variety of small point water supplies such as boreholes with handpumps, protected springs and dug wells [18], public taps, water purchased from vendors [19, 20]. A water crisis in the future will occur not because of actual physical scarcity of water rather because of continuing neglect of proper wastewater management practices [21].

According to BS 7799:1999 Part 1 risk assessment is defined as assessment of threats to, impacts on and vulnerabilities of information and information processing facilities and the likelihood of their occurrence. Risk assessment examines the severity or magnitude of risk to human health posed by contaminants [22]. A risk assessment report can be either quantitative or qualitative. In quantitative risk assessment, the probabilities of various adverse events and the likely extent of the losses, if a particular event takes place, are numerically determined. The risk assessment in developing countries possesses major challenges as the water supply distribution systems expand in an unplanned way and aging of pipes results into frequent leaks contributing to cross contamination and system loss. The objective of this study was to identify the potential physical risk to distribution system of Dhaka Water Supply and Sewage Authority (DWASA).

\section{Risk Assessment Method}

Risk assessment method includes the assessment of existing water supply distribution, potential sources to hazards. The assessment requires analyses of distribution system, its length, number of leaks in the pipes detected every month, population density, number of consumers, characteristics of areas whether industrial or residential areas, low lying and vulnerable to flooding. These data are collected and analyzed for preparation of risk maps. The number of leaks each month is collected with potential number of consumers which may be affected during leaks are determined. The details of the method is explained under the section Risk analaysis.

\section{Case Study Area}

The task of ensuring safe and sustainable drinking water for Dhaka city with a population of 14 million is getting difficult. The growth of population, economy and industry is a challenging factor for authorities like DWASA. The water supply is largely dependent on ground water, which is now seriously depleting. The peripheral river is highly contaminated due to unplanned industrial growth and poor sewage treatment facilities. It is becoming a difficult task for DWASA to find suitable location for intake of water.

\subsection{Sources}

Groundwater supplies are diminishing, with an estimated $20 \%$ of the world's aquifers being over-exploited [1]. The demand for water supply in Dhaka city has increased from 150 MLD (million litre per day) to 2240 MLD from 1963 to 2012 with number of deep tubewell increased from 30 to 622 over the same period. DWASA can supply only 2180 MLD against a demand of around 2240 MLD [23]. About $87 \%$ of Dhaka's water supply is coming from groundwater. Production capacity of surface water treatment plant is 535 MLD out of which 450 MLD is from Saidabad Water Treatment Plant, 39 MLD of Chadnighat Water Treatment Plant and 46 MLD of Narayanganj Water Treatment Plant. Apart from the rapid decline in groundwater table in Dhaka city the flow of river in Old Bhamaputra and Dhaleswari have reduced from 10\% to $4 \%$ of flow from river Jamuna. Most importantly, these perennial distributaries have become seasonal 
distributaries causing acute shortage of water during the dry season. The rivers are also badly affected by municipal and industrial wastewater.

\subsection{Distribution System}

DWASA distribution system has pipeline of nearly $3040 \mathrm{~km}$. The total number of consumers for DAWASA is residential 288,401 (92.71\%), commercial 19,872 (6.39\%). Piped water supplies are generally distributed according to three levels of services: house connections, yard connections and public standpipes. An assessment on the distribution system comprises of the types of materials used, age and size of the pipes and the location of the area susceptible to flooding. The system loss for Dhaka city is $28.8 \%$ [23]. Contaminated groundwater leaking into pipes is a major concern in the pipe network system of Dhaka city. This risk can be assessed by analysing the condition of the pipe such as age of the pipe, how rusty it has been; looking at pipe joints, pipe diameter as smaller pipes susceptible to beam failure; lengths to detect longitudinal breaks; materials type and corrosiveness of the soil. It is thus possible to identify leaks within the distribution system by analyzing the information related to pipe network system.

\section{Risk analysis}

The source-pathway-receptor model as shown in Fig. 2 below is important to identify risk of water supply system. The source-pathway-receptor model indicates that a hazard itself cannot possess risk unless there is a feasible pathway through which hazard may pass from the source to the receptor.
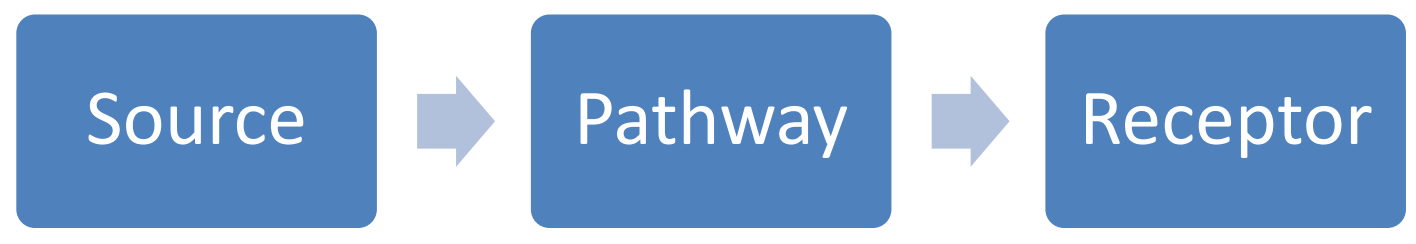

Fig. 2. Source-pathway-receptor model [24].

In risk analaysis, severity is measured in terms of the number of people being affected and the likely impact on those people from very little to lethal impact. Impact varies based on the type of hazards for examples pathogens and large scale pollution by chemicals may lead to mortality, whereas lower levels of chemical exposure may lead to morbidity. Both short-term and long-term exposures in relation to the impact should be taken into consideration for defining severity. Exposure of toxic chemicals such as arsenic possesses long-term affect resulting into higher severity as compared to non-toxic chemicals having shortterm impact. The geological characteristics of the site such as vulnerability to flooding, layout of pipe network on soft clay will be more prone to pipe failures and leakage. The leakage in major transmission pipes will affect more people as compared to subsidiary pipes affecting less people. The area being densely populated will have higher impact as compared to less densely populated area. The poorer communities will be more vulnerable to health impact as compared to the effluent communities who have much better access to health service.

Risks can be identified at various stages, and prioritized in terms of likelihood and severity [25]. A riskranking matrix addresses both likelihood and severity. In this case, semi-quantitative ranking system is used by allocating numbers to different levels of likelihood and different levels of severity. A risk score is then calculated as a product of likelihood and severity as shown below:

$$
\text { Risk }=\text { Likelihood } * \text { Severity }
$$

The selection of the criteria and the weighting used for different criteria with descriptions are provided in Table 1 below as there is no uniform 'industry standard'. 
Table 1. Risk Analysis for Water Supply System [26, 27]

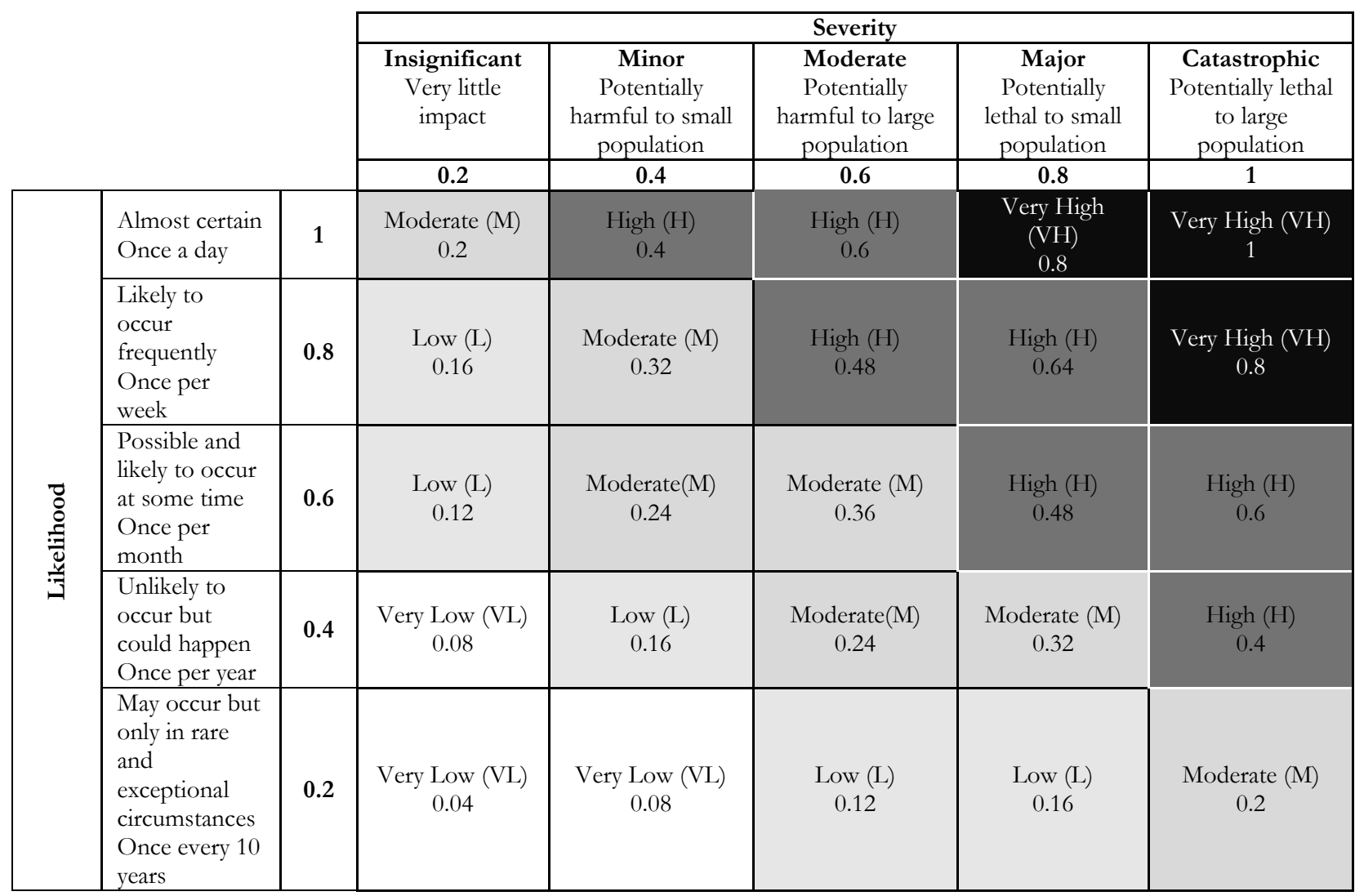

The weightings used in Table 1 were applied for risk assessment of water system in South-East Water, Australia [26] and in Uganda [27]. The risk score ranging from 0-0.08 indicates very low risk based on the livelihood and severity, the score of 0.081-0.16 indicates low risk, the score of 0.17-0.36 indicates moderate risk, the score of 0.37-0.64 indicates high risk and the score over 0.64 indicates very high risk. Assessing the likely impact of the severity of distributed water supply through pipeline is based on the following severity scale resulted from water borne diseases as shown in Table 2 .

Table 2. Likely health impact of the severity of distributed water supply through pipeline.

\begin{tabular}{lccccc}
\hline Severity Scale & 0.2 & 0.4 & 0.6 & 0.8 & 1 \\
\hline Likely Impact & No water borne & No water borne & Water borne & Severe water & Very severe life- \\
& diseases & diseases but & diseases & borne diseases & threatening event \\
& requiring & requiring & requiring & requiring urgent & due to water \\
& hospital & hospital & hospital & hospital & borne diseases \\
& treatment & treatment & treatment & treatment & \\
\hline
\end{tabular}

Very high risk indicates that the water contamination takes place by faecal pollution from the area resulting from leak at least once a day or a week and at least over 30\% people are vulnerable. High risk arises when the water contamination occurs due to leaks at least once a week to a month and at least 5-30\% people are vulnerable. Moderate risk occurs when 1-5\% people are vulnerable resulting from leaks at least once a week to a month. Finally, there is a low risk when the pipe exposes to leak at least once a month to a year, affecting, less than $1 \%$ of the population in the area.

The population densities for various zones are calculated. Population exposed to contamination is calculated by multiplying the population density with the buffer area having a radius of $100 \mathrm{~m}$ around each number of points where leak is detected as shown in Table 3 . The risk analysis was carried out based on the frequency of occurrence or likelihood and severity in terms of exposed population and risk score is calculated as per Table 4. 
Table 3. Population exposed to contaminated water resulting from leaks.

\begin{tabular}{lcccccc}
\hline Zone & $\begin{array}{c}\text { Ave. Leak } \\
\text { per month }\end{array}$ & Population & $\begin{array}{c}\text { Population } \\
\text { Density/km }\end{array}$ & $\begin{array}{c}\text { Exposed } \\
\text { Population }\end{array}$ & $\begin{array}{c}\text { \% of Total } \\
\text { Exposed } \\
\text { Population }\end{array}$ & $\begin{array}{c}\text { Evaluation of } \\
\text { Exposed } \\
\text { Population }\end{array}$ \\
\hline Zone I & 21 & 1082400 & 34623.19 & 231929 & 4.51 & Low \\
Zone II & 39 & 1666896 & 117814.44 & 1442756 & 28.08 & Very High \\
Zone III & 36 & 1017456 & 35330.81 & 394757 & 7.68 & Moderate \\
Zone IV & 93 & 1619270 & 54082.88 & 1575083 & 30.66 & Very High \\
Zone V & 26 & 1762147 & 99058.04 & 811302 & 15.79 & High \\
Zone VI & 34 & 1255584 & 37832.95 & 398955 & 7.77 & Moderate \\
Zone VII & 26 & 317576 & 9042.38 & 73822 & 1.44 & Low \\
zone-VIII & 10 & 1000138 & 17652.99 & 52659 & 1.02 & Low \\
Zone-IX & 24 & 982819 & 13126.89 & 97894 & 1.91 & Low \\
Zone-X & 28 & 259776 & 6795.60 & 58680 & 1.14 & Low \\
\hline
\end{tabular}

Table 4. Risk Assessment of various zones of DWASA.

\begin{tabular}{lcccccccc}
\hline Zone & $\begin{array}{c}\text { Almost } \\
\text { once a } \\
\text { day }\end{array}$ & $\begin{array}{c}\text { Almost } \\
\text { once a } \\
\text { week }\end{array}$ & $\begin{array}{c}\text { Once a } \\
\text { month }\end{array}$ & $\begin{array}{c}\text { Once } \\
\text { a year }\end{array}$ & $\begin{array}{c}\text { Exposed } \\
\text { Population }\end{array}$ & $\begin{array}{c}\text { Weightage } \\
\text { for Severity } \\
\text { in terms of } \\
\text { exposed } \\
\text { Population }\end{array}$ & $\begin{array}{c}\text { Risk } \\
\text { Score }\end{array}$ & Evaluation \\
\hline Zone I & & 0.8 & & & Low & 0.4 & 0.32 & Moderate \\
Zone II & & 0.8 & & & Very High & 0.6 & 0.48 & High \\
Zone III & & 0.8 & & Moderate & 0.6 & 0.48 & High \\
Zone IV & 1 & & & Very High & 1.0 & 1.0 & Very High \\
Zone V & & 0.8 & & High & 0.8 & 0.64 & High \\
Zone VI & & 0.8 & & & Moderate & 0.6 & 0.48 & High \\
Zone VII & & 0.8 & & Low & 0.4 & 0.32 & Moderate \\
Zone-VIII & & 0.6 & & Low & 0.4 & 0.24 & Moderate \\
Zone-IX & & 0.8 & & Low & 0.4 & 0.32 & Moderate \\
Zone-X & & 0.8 & & Low & 0.4 & 0.32 & Moderate \\
\hline
\end{tabular}

The number of leaks for various zones of Dhaka city were obtained from DWASA and analysed as shown in Fig. 3. A risk map as shown in Fig. 4 is prepared based on based on obtained score.

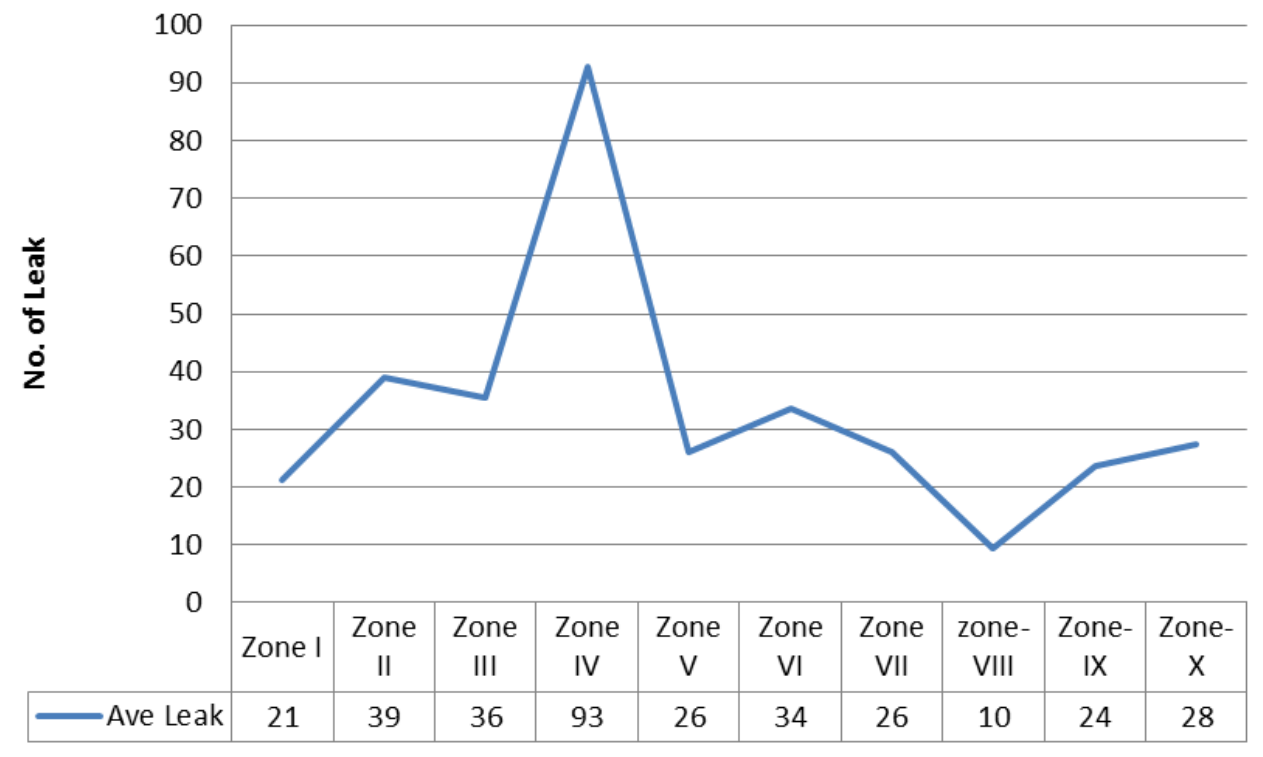

Fig. 3(a). Average leak per month for various zones of Dhaka city (Year 2012-2013). 


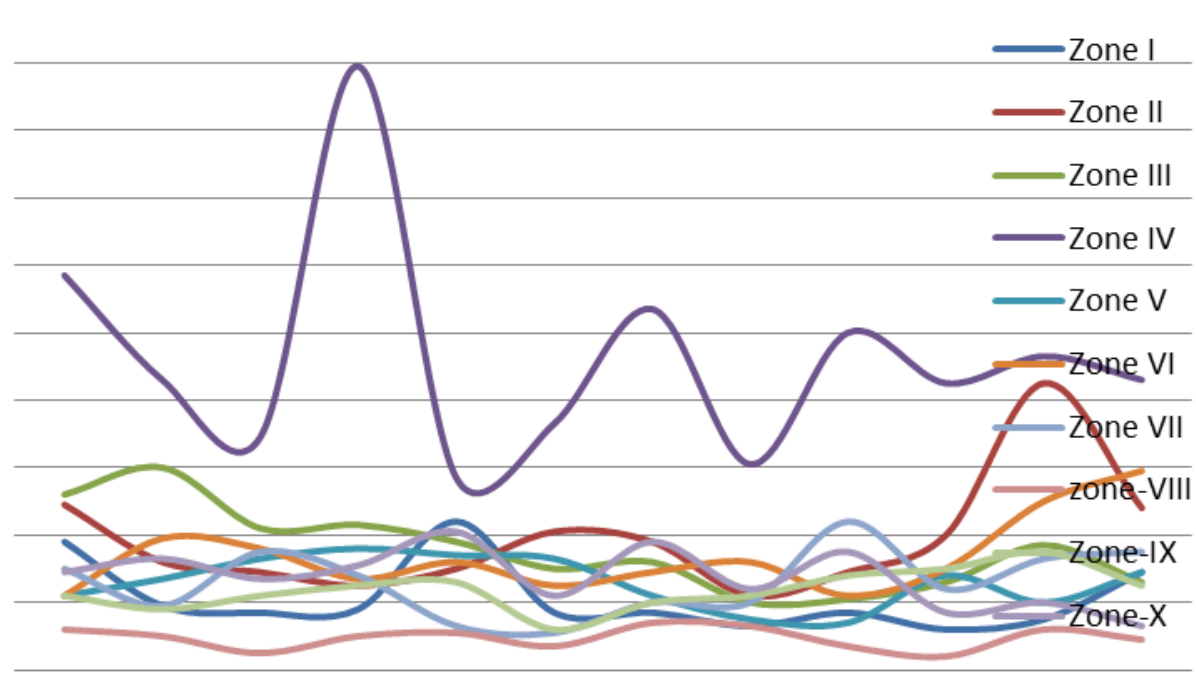

Fig. 3(b). Monthly variation of leak for various zones of Dhaka city.

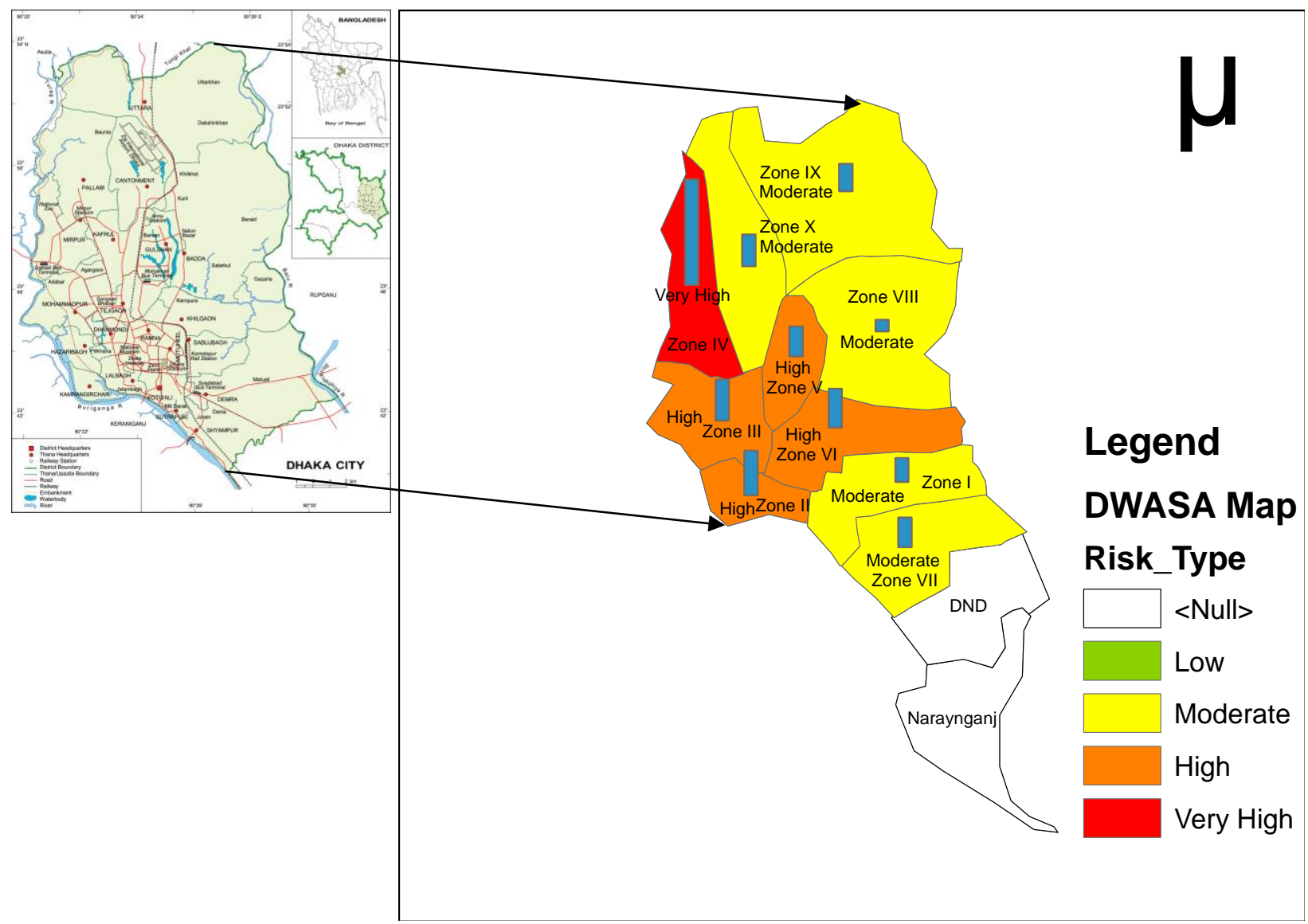

Fig. 4. Risk analysis map zone-wise of DWASA.

It is observed that Zone IV is a very high risk zone in terms susceptibility to leaking. The Zone IV has the highest leak of 93 per month and major leak occurred during the month of April. Zone IV consists of Mirpur area with 1,575,083 people exposed to water contamination. The poor infrastructure comprising of old aged pipes, low lying areas often water logged during rainy season followed by a number of illegal connection is the major reason. The roads are frequently dug and pipelines are affected. However, DWASA 
awarded TEDAGUA for the restoration of the water conduits in Zone IV of Mirpur area by replacing a total of $509 \mathrm{~km}$ (diameters $90-600 \mathrm{~mm})$ made of high-density polyethylene $(348 \mathrm{~km})$ and PVC $(161 \mathrm{~km})$.

The requirement for water demand in Zone IV is 320 MLD while it can produce only 185 million litres per day with existing facilities. There is a shortage of 135 MLD and to overcome this shortage the zone authority has to ration water. Zone II, III, V and VI comprising Hazaribag, Mohammadpur, Kafrul and Tejgaon respectively are old and congested areas with poor infrastructures are considered as high risk zones as shown in Table 3. A number of slums are located in these areas and sometimes there are illegal connections made through the major pipes resulting in leakage and wastage of water. Zone VI is an industrial area having many food processing and beverage industries. The wastage of water resulting from leakage may affect businesses indirectly by affecting water used for cooling and food production. The Zone I, VII, VIII, IX and X are moderate risk zones. Zone VIII comprising of Gulshan area, has the least average number of 10 leaks per month. Gulshan is mainly a residential area with dwellers from affluent society. A number of houses and offices in these areas use bottled water due to affordability. The area was developed in the late $80 \mathrm{~s}$ and the old pipelines were replaced with new ones very recently. There are couple of slum areas (one of them Korail Slum, largest in Dhaka) around the area where some illegal water connection may exists resulting in leaks. Zone IX consists of Basundhara area has moderate risk where development took place quite recently and the pipelines are still in good conditions. The monthly average number of leaks is 24 due to poor condition of existing roads resulting from movement of heavy traffic for construction of new buildings. Zone I and VI comprising of Motijheel and Ramna are old and congested areas and old pipes were replaced very recently with the new ones and hence the risk is moderate.

\section{Conclusions}

Risk assessment with risk matrices and analysis of risk using weighting and scoring is a useful method. Zone IV having an area of $29.98 \mathrm{sq}$. km possesses very high risk with 1,571,960 people vulnerable. The Zone II, III, V and VI have high risks followed by other Zones I, VII, VIII, IX and X as moderate risk zones. By developing risk assessment, the authority of DWASA will be able to take necessary measures to divert more resources to the very high risk zone and carry out regular monitoring to develop operational plans and identify key priorities for action. Upgrading water supply based on risk assessment can reduce vulnerability of people being affected by water borne diseases. A number of factors such as age of pipes, vulnerability to flooding, pipe materials and layout subjected to frequent excavation or repair works of roads along the pipelines are responsible for leaks. The water gets easily contaminated where leak occurs and severity is more where population density is rather high. Water shortages are anticipated to rise in the coming days influenced by further growth of population and impact of climate change. Therefore, it is important that DWASA prepares an effective plan in monitoring leaks and reduce system loss to make the distribution system more effective.

\section{References}

[1] WWAP, “The United Nations world water development report 2014," Paris, United Nations World Water Assessment Programme, UNESCO, 2014.

[2] J. C. Padowski and S. M. Gorelick, "Global analysis of urban surface water supply vulnerability," Environmental Research Letters, vol. 9, no. 10, p. 104004, 2014. doi:10.1088/1748-9326/9/10/104004

[3] UNOSD/UNU (United Nations Office for Sustainable Development/United Nations University), "Water for sustainability: framing water within the post-2015 development agenda," Incheon/Hamilton, Republic of Korea/Canada, UNOSD/UNU, 2013.

[4] WWAP, "The United Nations world water development report 2015: Water for a sustainable world," Paris, United Nations World Water Assessment Programme, UNESCO, 2015.

[5] S. Wallace, J. Corinne, V. I. Grover, Z. Adeel, U. Confalonieri, and S. Elliott, Safe Water as the Key to Global Health. Hamilton, Canada: United Nations University International Network on Water, Environment and Health, 2008.

[6] N. J. Marobh, G. Renman, and G. Jacks, "The study of water supply and traditional water purification knowledge in selected rural villages in Tanzania," in Indigenous Knowledge Systems and Sustainable Development: Relevance for Africa. Tribes and Tribals Special Volume 1, E. K. Boon and L. Hens, Eds. Kamla-Raj Enterprises, 2007, ch. 11, pp. 111-120. 
[7] UN Water, "International year for sanitation Factsheet 1-Sanitation is vital for health," UN Water, New York, 2008.

[8] WHO and UNICEF (World Health Organization/United Nations Children's Fund), Progress on Drinking Water and Sanitation: 2014 Update. New York: WHO/UNICEF Joint Monitoring Programme for Water Supply and Sanitation, 2014.

[9] G. Howard and J. Bartram, "Effective approaches to water supply surveillance in urban areas of developing countries," Journal of Water and Health, vol. 3, no. 1, pp. 31-43, 2005.

[10] K. K. Gajanan, D. K. Moromi, S. N. Pimpalkar, and P. K. Labhasetwar, "Surveillance of drinking water quality for safe water supply-A case study from Shillong, India," Water Resources Management, vol. 25, no. 13, pp. 3321-3342, 2011.

[11] R. Meinzen-Dick, "Water reallocation: Challenges, threats, and solutions for the poor," No. HDOCPA-2006-41. Human Development Report Office (HDRO), United Nations Development Programme (UNDP), 2006.

[12] A. K. Gain and Y. Wada, "Assessment of future water scarcity at different spatial and temporal scales of the Brahmaputra River Basin," Water Resources Management, vol. 28, no. 4, pp. 999-1012, 2014.

[13] N. F. Gray, Water Technology an Introduction for Environmental Scientists and Engineers, 2nd ed. Elsevier, 2008.

[14] UN-Habitat, "State of the World's Cities 2010/2011 Report: Bridging the Urban Divide," Nairobi, UN-Habitat (United Nations Human Settlements Programme), 2010.

[15] UNDSEA. (2014). 2014 Revision of the World Urbanization Prospects. United Nations Department of Economic and Social Affairs, New York. [Online]. Available: http://www.un.org/en/development/desa/publications/2014-revision-world-urbanizationprospects.html.

[16] S. Shams, M. C. M. Shohel, and A. Ahsan, "Housing problems for middle and low income people in Bangladesh: Challenges of Dhaka Megacity," Environment and Urbanization Asia, vol. 5, no. 1, pp. 175 184, 2014.

[17] M. K. Perrson, "Tap, tank or bottle?-Aspects of drinking water consumption," in Drinking WaterSources, Sanitation and Safeguarding, J. Forare, Ed. Formas, 2009, pp. 113-133.

[18] G. Howard, J. K. Bartram, and P. G. Luyima, "Small water supplies in urban areas of developing countries," in Providing Safe Drinking Water in Small Systems: Technology, Operations and Economics, J. A. Cotruvo, G. F. Craun, \& N. Hearne, Eds. Washington, D.C.: Lewis Publishers, 1999, pp. 83-93.

[19] G. Howard, "Challenges in increasing access to safe water in urban Uganda: Economic, social and technical issues," in Safety of Water Disinfection: Balancing Microbial and Chemical Risks, G. F. Craun, F. S. Huachman, and D. E. Robinson eds). ILSI Publications, Washington, D.C., pp. 483-499.

[20] T. T. Tatietse and M. Rodriguez, "A method to improve population access to drinking water networks in cities of developing countries," Journal of Water Supply Resources and Technology-AQUA, vol. 50, no. 1, pp. 47-60, 2001.

[21] O. Varis, "More urban and more aged: Demographic pressures to global water resources by 2050," in Water Resources Development and Management, A. K. Biswas and Cecilia Tortajada, Eds. Springer, 2009, pp. $1-35$.

[22] T. H. Wen, N. H. Lin, C. H. Lin, C. C. King, and M. D. Su, "Spatial mapping of temporal risk characteristics to improve environmental health risk identification: A case study of a dengue epidemic in Taiwan," Science of the Total Environment, vol. 367, no. 2, pp. 631-640, 2006.

[23] [23] DWASA (2012). Annual Report 2011-12, Dhaka Water Supply and Sewerage Authority (DWASA), June 2012, Dhaka.

[24] S. Godfrey and G. Howard, "Water safety plans (WSP) for urban piped water supplies in developing countries," WEDC, Loughborough University, UK, 2004.

[25] Asian Development Bank (ADB). (2010). Guidance Note: Urban Water Supply Sector Risk Assessment, Mandaluyong City, Pbilippines. [Online]. Available: http://www.adb.org/sites/default/files/pub/2009/Guidance-Note-Urban-Water-Supply-SectorRisk-Assessment.pdf, Accessed: 10 Dec. 2013.

[26] D. Deere, M. Stevens, A. Davison, G. Helm, and A. Dufour, "Management strategies," in Water Quality: Guidelines, Standards and Health, L. Fewtrell and J. Bartram, Eds. London: IWA Publishing, 2001, pp. 257-288.

[27] S. Godfrey, C. Niwagaba, G. Howard, and S. Tibatemwa, "Water Safety Plans for developing countries-A case study from Kampala, Uganda,” WEDC, UK, 2002. 